\title{
Legal Clinical Education: Ukrainian Experience
}

\section{Educación clínica legal: experiencia ucraniana}

\author{
Maryna I. Saienko \\ Dnipropetrovsk State University of Internal Affairs, Dnipro, Ukraine \\ ORCID: https://orcid.org/0000-0003-1768-2143 \\ Liudmyla M. Dobroboh \\ Dnipropetrovsk State University of Internal Affairs, Dnipro, Ukraine \\ ORCID: https://orcid.org/0000-0002-7149-7697

\section{Inna O. Pozigun} \\ Odessa State University of Internal Affairs, Odessa, Ukraine \\ ORCID: https://orcid.org/0000-0003-4781-8259

\section{Olena O. Orlova} \\ Dnipropetrovsk State University of Internal Affairs, Dnipro, Ukraine \\ ORCID: https://orcid.org/0000-0001-7707-4612
}

*Correspondence

Email: mar.saienko@uohk.com.cn
Cite as:

Saienko, M. I., Dobroboh, L.M., Pozigun, I.O., Orlova. O.O., (2020). Legal Clinical Education: Ukrainian Experience. Propósitos y Representaciones, 8 (SPE2), e686. Doi: http://dx.doi.org/10.20511/pyr2020.v8nSPE2.686 


\section{Summary}

The relevance of the article is stipulated by the necessity to study a specific type of legal education - legal clinical education. However, legal clinics are the basis for the practical training and students' practice implementation i.e. they allow to transfer the obtained theoretical knowledge into the practical ones. The purpose of the study is to analyze the peculiarities of formation and development of the abovementioned education in Ukraine in general, and in imitation of the Legal Clinic "Istyna" of Dnipropetrovsk State University of Internal Affairs activities, in particular, as well as to determine the prospects of the legal clinical movement. The basic methods in the study of this issues are the following: the historical method; the method of analysis. The method of prediction to determine the prospects for the further development of legal clinical education in Ukraine in the context of integration into the European educational area and the Concept of Legal Education Development was also applied. The article elucidates the concept "legal clinical education", focuses on the necessity for this type of education, and determines the prospects of achieving quality results of legal clinical education, taking into account its components in the domestic legal education by the imitation of the legal clinic "Istyna" of Dnipropetrovsk State University of Internal Affairs. The materials of the article may be useful in future studies of the legal clinics activities and functioning and implementation of the concept legal of education development in Ukraine.

Keywords: Right to Education; Legal Education; Rule of Law; Legal Clinic.

\section{Resumen}

La relevancia del artículo está estipulada por la necesidad de estudiar un tipo específico de educación jurídica: la educación clínica legal. Sin embargo, las clínicas legales son la base para la capacitación práctica y la implementación práctica de los estudiantes, es decir, permiten transferir el conocimiento teórico obtenido a los prácticos. El propósito del estudio es analizar las peculiaridades de la formación y el desarrollo de la educación mencionada en Ucrania en general, y en imitación de las actividades de la Clínica Legal "Istyna" de la Universidad Estatal de Asuntos Internos de Dnipropetrovsk, en particular, así como determinar Las perspectivas del movimiento clínico legal. Los métodos básicos en el estudio de estos temas son los siguientes: el método histórico; El método de análisis. También se aplicó el método de predicción para determinar las perspectivas de un mayor desarrollo de la educación clínica jurídica en Ucrania en el contexto de la integración en el área educativa europea y el Concepto de desarrollo de la educación jurídica. El artículo aclara el concepto de "educación clínica legal", se centra en la necesidad de este tipo de educación y determina las perspectivas de lograr resultados de calidad de la educación clínica legal, teniendo en cuenta sus componentes en la educación jurídica nacional mediante la imitación de la ley. clínica "Istyna" de la Universidad Estatal de Asuntos Internos de Dnipropetrovsk. Los materiales del artículo pueden ser útiles en futuros estudios sobre las actividades de las clínicas legales y el funcionamiento e implementación del concepto legal del desarrollo educativo en Ucrania.

Palabras clave: Derecho a la educación; Educación jurídica; Estado de derecho; Clínica jurídica.

\section{Introduction}

The modern education system is more focused on theoretical training. Clinical legal education compensates this higher legal education system disadvantage to some extent. In our opinion, a significant part of the educational process should have a practical direction or the correlation of 
theory and practice should be in equal proportions at least. "Improving the quality of higher legal education directly depends on the inclusion of practice-oriented components into it. In this regard, it is necessary to develop clinical training in the process of future lawyers training on the basis of legal clinics functioning as structural units of higher educational institutions" indicate T. Khudoykina and V. Lysenko (2017). It has been widely acknowledged that pro bono service in law clinics and university access to justice initiatives have a positive impact on students, especially in relation to increasing their graduate employability skills (Cantatore, 2020).

The clinics system focuses not on the theoretical fruits of legal science, but on acting law. While studying theory, students cognize law basics, and while being in practice they learn to apply the acquired theoretical knowledge. There is a certain type of activities, helping a student to apply his knowledge, such as: giving of consultations, providing legal assistance to citizens, informing citizens on human rights. It is interesting that the law schools, whose students have shown the best results in passing the single professional entrance examination to the magistracy on "Law", mostly possess legal clinics (Vlasiuk, 2018).

The transformations and changes that are currently taking place within our society as a result of the European integration course, are affecting different areas. Legal education is no exception. This has led to focusing attention of scholars and practitioners to the activities of legal clinics as inherent part of a quality legal profession. The issues of improving the legal education and training of qualified professionals are of particular importance. Art. 8 of the Constitution of Ukraine (1996), states that the rule of law is recognized and implemented in Ukraine. In order "the rule of law" term to be of high quality, we should get over a difficult and long way. How quickly we overcome it depends, above all, on the activities of representatives of our profession. Undoubtedly, legal community should take responsibility for the state of human rights protection and for the development of a democratic, law-based state in Ukraine.

There are about 200 higher education institutions in Ukraine, training lawyers. There are about 100 legal clinics, where students possess an opportunity to practice and increase their level of knowledge. Although, according to the Order of the Ministry of Education and Science of Ukraine "On Approval of the Standard Regulation on the Legal Clinic of a Higher Educational Institution of Ukraine", legal clinics should function at all educational establishments of III-IV levels of accreditation, training specialists in "Law", regardless of the form of ownership and subordination (Order of the Ministry of Education... 2006). With regard to the concept "legal clinical education", it is not enshrined normatively and is defined variously. There are virtually no fundamental studies of this category in domestic scientific literature, which significantly complicates its unambiguous understanding and use. Mostly it is used in scientific researches to characterize the unique way of training specialists in the field of "Law" (with the obligatory use of legal clinics in the educational process as a basis for students to obtain additional theoretical knowledge and practical skills) (Halai, 2005). Thus, the following issues remain unresolved today: the extent to which the legal education system meets the needs of the state and society; to what extent the level of students training meets the legal education quality standards; the role of legal clinical education within legal education.

\section{Materials and methods}

The following methods were used during the research: historical method (allowed to find out the processes of origin, formation and development of the clinical movement in Ukraine, taking into account the specific historical environment where the formation of legal clinics took place, which, in turn, helped to understand correctly the essence of the category under study); method of analysis (provided an opportunity to study the legal clinics activities in Ukraine in imitation of the Legal Clinic "Istyna" of Dnipropetrovsk State University of Internal Affairs) and method of predicting (allowed to determine the prospects of further development of legal clinical education 
in Ukraine in the context of integration to the European Educational Area and the Concept of Legal Education Development). The results of the legal clinic "Istyna" of Dnipropetrovsk State University of Internal Affairs activities have become the basis for the study.

Problems of legal clinics activities and functioning are dealt with by scientists. An important scientific, theoretical and applied study of legal clinics activities is the paper of $\mathrm{M}$. Lodzhuk (2015) "Legal Clinics in Ukraine: Education and Legal Assistance", where he focuses, in particular, on the general and theoretical characterization of the content of legal regulation of legal clinics activities in Ukraine". Separate aspects of paper of A. Halai $(2005 ; 2009)$ are devoted to some aspects of the legal education improving and the introduction of subjects and courses on legal clinical activities and practice into the educational process; the papers of K. Levitan and M. Yuhova (2004) E. Meshcheryakov and A. Petrushin (2013) deal with raising the legal awareness and professional competence of students. Yu. Figel' (2011) research was devoted to clarifying the role of legal clinics in the process of forming the ability to implement law by law students in 2011. Significant contribution to the development of clinical education are the papers devoted to the features of emergence and functioning of legal clinics in foreign states with the legal system of the Anglo-American type (Dubchak, 2013), the role of legal clinics in law education (Sokolenko, 2009) and the study of the genesis of legal clinical education (Polyakov, 2010).

As we can see, there are a number of papers dedicated to legal clinics. However, the study aimed at clarifying the needs of the state and students regarding the quality standards of legal education; determining the place of legal clinical education in legal education; identification of peculiarities of emergence, establishment and functioning of legal clinics in higher education institutions in Ukraine, establishing their role in the practical aspect of training students for the future profession has not been carried out.

\section{Results and discussion}

Thus, there is the necessity for legal clinics and the clinical movement is gaining popularity in Ukraine. Analysis of foreign and domestic scientific literature on legal education and legal clinical activities, on regulatory and legal support in national and European educational areas, has led to the conclusion that legal clinics today can provide effective activities in the field of law and legal clinical activities are now an integral part of legal education.

As a result of the study of the experience of functioning of the legal clinic "Istyna" of Dnipropetrovsk State University of Internal Affairs, we can point to the formation of a special type of legal education, such as legal clinical education and the expediency of using the concept "legal clinical education", which should be understood as a way of acquiring of practical skills of a lawyer by provision of free legal assistance to the population by the students within the framework of practice on the basis of a legal clinic of a higher educational institution. The purpose of legal clinical activities is to provide students with practical professional skills by way of free legal assistance to the population provision, informing citizens on human rights.

The attempt of a comprehensive study of legal clinical education by example of the Legal Clinic "Istyna" of Dnipropetrovsk State University of Internal Affairs has revealed a number of urgent issues the solution of which requires considerable attention in scientific and practical terms. However, consolidation of students' theoretical knowledge and getting practical skills of a lawyer, formation of respect for the principles of law, raising the level of legal culture of the population, as well as providing free legal assistance to those who need it are undeniable. All this testifies to the actualization of the legal clinical movement and education.

Regarding the quality of legal education, it should be noted that Ukraine, which joined the Bologna process back in 2006, has undertaken a number of commitments to improve education, in particular, through the introduction of appropriate educational standards. 
Development and implementation of state standards of legal education, including branch standard of higher legal education and standard of higher legal education of educational establishments, will promote its improvement and will allow carrying out an assessment of its quality. Pursuant to the Draft Concept for the Development of Legal Education (2020), achieving strategic goal 5. "Law schools provide high-level practitioners' applied practical skills and abilities" is anticipated assistance to the development of legal clinics in the form of separate structural units of higher education institutions and implementation of training courses in legal clinical practice into educational process, and one of the indicators of achievement is an increase in the percentage of involvement of students in participating in legal clinics activities.

An attempt at a comprehensive study of legal clinical education has exposed a number of urgent issues, solution of which requires considerable attention in both scientific and practical terms. It concerns, firstly, the necessity to determine the content of a category "legal clinical education" and its place in legal education; secondly, the improvement of the legal training system, since legal clinical education is a way to acquire the practical skills of a lawyer by providing free legal assistance to the population for students while practicing in legal clinic; third, it is precisely due to legal clinical education that we are able to get as close as possible to the standards of the European legal education, where the practical component plays a key role.

"An important component of legal education is the practical one. ... Practical component also determines the necessity to change forms of classroom activities with students, the use of interactive teaching methods, in particular, the case method. Introducing legal clinical education is a crucial area of legal education improving" - noted Yu. Zavhorodnia, A. Kuchuk, L. Serdyiuk (Kuchuk et al. 2019). But there is a shot excursus on history at first. In independent Ukraine, the implementation of interest in the practical aspect of the lawyers training took place in 1996, when the first law clinic in the country named "Pro bono" was opened at the Taras Shevchenko National University of Kyiv. (Polyakov, 2010). Since then, legal clinics have emerged in virtually all higher education institutions in Ukraine that provide training for lawyers. A. Halai (2009) points out that the legal clinic today is involved in the realization of two constitutional human rights the right to education and the right to legal assistance. It is known that human rights and freedoms and their guarantees determine the content and direction of the state. Human rights and freedoms promotion and provision is central responsibility of the state.

After active development during 1999-2006, there was a certain decline in interest in legal clinical education. An all-Ukrainian non-governmental organization, the Association of Legal Clinics of Ukraine, as an informal public community, was established in 2003, in order to ensure and further enhance the benefits of "clinical education". These organization activities are aimed at supporting the legal clinics of Ukraine functioning. To date, the register of legal clinics of Ukraine numbers 50 clinics, including 2 candidates for association. Although there are still 2 dozen clinics that are established and functioning but are not members of the Association (Register of Legal..., 2019). Interest in legal clinical education began to increase in 2013-2014: national conferences of legal clinics were restored, the Association of Legal Clinics of Ukraine activities were revived, a number of seminars, trainings and competitions were held. At the beginning of 2014, up to 60 legal clinics were active at higher education institutions in Ukraine, which actively participated in providing access to free legal aid for the disadvantaged population (Halai, 2014). According to the Association of Legal Clinics of Ukraine (2019), there are already about 100 legal clinics operating in the country and their number is increasing.

Therefore, it may be a matter of active development of legal clinical education within the scope of legal education. The concept "legal clinical education" is not enshrined at the legislative level in Ukraine, but despite the lack of such type of legal education as clinical one in acting law, more and more scholars and practitioners are using this concept. Thus, according to Yu. Figel (2011), legal clinical education is a specific program of professional training of students of law 
specialties, implemented on the basis of legal clinics, aimed at filling the gap that arises between the obtained theoretical knowledge and their application in practice, and which contributes to law implementation skills formation by students studying there. As Yu. Savelova (2013) neatly remarks, legal clinics functioning at higher legal educational establishments is quite justified, since on the one hand, a large number of low-income persons apply to them for free legal aid, and on the other hand, having graduated from higher educational institution, students acquire some experience of professional practical activities that allows them to be competitive in the labor market. In this regard, legal clinical education in the sense of its integration into the existing system of traditional higher education is positive in view of the fact that it does not deny it, and it is not a radical means of reforming it, but provides a smooth "growth" of new methodological approaches, modern forms and teaching methods into it (Nemytina, 2004).

T. Khudoykina notes that "clinical legal training allows students to learn how to provide legal aid qualitatively and effectively: to deal with clients, to prepare the necessary documents, etc. Throughout, the aim of establishing and functioning legal clinics should be to increase the practical (professional) level of legal education at on the basis of special training and to provide real legal services to the population at no cost. Providing legal services by future lawyers, engaging them in work, for example, with human rights organizations (bar associations), provides an opportunity to improve their knowledge and gain practical skills during their studies at the university. Therefore, clinical legal education is aimed at changing the very vector of training. As a rule, this vector is directed from theory to practice, so the student is first forced to master theoretical provisions and then to realize where they can be applied" (Khudoykina, 2014).

Therefore, legal clinical education provides for: a combination of theoretical education and practical skills; conducting special classes at a legal clinic to prepare students for practical activities; advising clients by students under the supervision of tutors with hands-on experience; democratic style of teacher-student relations; development of professionally important qualities, including emotional intelligence and ethics in students. Thus, legal clinical education should be understood as a way to acquire the practical skills of a lawyer by students by providing free legal assistance to the population in the framework of educational and other types of practice at the legal clinic of a higher education institution.

Features of legal profession require constant improvement of theoretical knowledge and skillful implementation of them in practice. That is why legal clinics are established at higher educational establishments. In addition, almost every university is currently concerned with the organization of students' practice. Not all institutions are happy to take students to practice, some only accept students from predefined institutions of higher education, that is, students themselves should find practice placement. Quite common are cases where a student's practice at a particular institution is limited only by staying of a student in its walls for a certain period of time without real acquaintance with the work. It is difficult to call such practice productive. Clinic for higher education institution is a place where the student will be able to practice law, to practise it in accordance with the tasks of the educational process, curriculum and under the guidance of his lecturers.

Dnipropetrovsk State University of Internal Affairs responds to current trends and existing needs in the field of providing quality legal education, so at its base the Legal Clinic "Istyna" was established and functions since 2001. It first functioned as the Legal Aid Center "Istyna", which was reorganized into a legal clinic in 2013. According to the Regulations on the Legal Clinic "Istyna" of Dnipropetrovsk State University of Internal Affairs (Regulation "On the Legal Clinic..., 2017), the Legal Clinic "Istyna" of Dnipropetrovsk State University of Internal Affairs is the basis for the practical training and academic practice of higher education applicants.

The main purpose of the legal clinics establishment and functioning is to develop students' professional activities skills, to acquire theoretical knowledge and lawyer's practical skills, to form students' respect for the principles of law, to increase the level of legal culture of 
the population, as well as to provide socially vulnerable groups of population with free primary legal aid. Legal Clinic "Istyna" is a member of the Association of Legal Clinics of Ukraine and actively cooperates with public authorities, international organizations and public associations. Particular attention should be paid to the fact that in the Legal Clinic "Istyna" of Dnipropetrovsk State University of Internal Affairs activities actively participate invited practitioners, who join the consulting of clients, conducting workshops, trainings, interviews, as well as organizations, with which close contacts have been established in order to achieve a positive result in solving the clients' issues.

In order to provide free legal assistance in the field of human rights and freedoms protection at the legal clinic, a hot line is operating - the Call-center of the Legal Clinic "Istyna", which performs subsidiary advisory function and a gender advisory and information center, performing an advisory function within the legal clinic for persons who need free legal and psychological support and have suffered from gender inequalities, gender-based violence, including domestic violence. Legal Clinic "Istyna" pays great attention to scientific researches in the field of legal clinical activities, the results of which are reflected in the publication of a number of scientific papers, professional scientific articles and abstracts of scientific reports in the proceedings of conferences in Ukraine and abroad. Legal clinic students are constantly upgrading their knowledge and have a high level of practical skills, enabling them to provide free legal aid. In the case of certain difficulties, qualified lecturers are involved in providing legal advice; they together with the students take a comprehensive approach to solving the issues that clients are applying with.

According to the Regulations on the Legal Clinic "Istyna" of Dnipropetrovsk State University of Internal Affairs (Regulation "On the Legal Clinic..., 2017), the main tasks of the Legal Clinic are: acquisition of lawyer's practical skills by students; establishment of abilities for students to do their practical training; provision of free legal and psychological assistance to not sufficiently provided citizens; carrying out measures on informing people about human rights and fundamental freedoms. Thus, the presence of functioning legal clinics for the process of becoming a law student as a specialist is beyond of doubt. Therefore, the positive components in favor of legal clinical education are: the opportunity to get acquainted with the practical side of the chosen specialty, because clinical legal education increases the possibilities of practical activities of students; promoting the provision of free legal aid to those who not provided sufficiently to pay a lawyer; informing citizens on human rights and fundamental freedoms.

However, there are a number of challenges faced by legal clinics, namely: this type of workload is not provided for by the staffing of educational institutions; the lack of proper recognition of clinical training at the formal level significantly complicates the selection of legal clinic lecturers; this work cannot be equated to workload as a practice guiding, since working with students in a legal clinic is not only more difficult in content but also requires a considerable amount of time. "Absence of clear regulation of legal clinics organization and functioning at the legislative level, uncertainty of the status of legal clinics in the higher vocational education system, issues of financing of clinics and remuneration of their staff, lack of qualified personnel capable and willing to teach students practical skills, lack of mandatory requirements (normative standards and their resource reinforcement) of clinic activities" point T. Khudoykina and V. Lysenko (2017) analyzing the issues of contemporary clinical education as an important component of legal education.

In Ukraine, we have a paradoxical situation: higher education institutions do not want at least some of them to establish such a course, because it allegedly entails considerable financial, organizational costs and another important argument is that such a course will be a repetition of other existing ones, giving students practical skills, or there are some beliefs about the worthlessness of clinics. That is why sometimes student societies organize the legal clinic 
themselves and solve all effective functioning challenges. There are also situations where the administration opposes the creation of such a course because they do not like the very idea and philosophy of the legal clinic. The efficiency of the legal clinic is achieved through the constant supervision and assistance of the lecturer-manager of the legal clinic. This condition is not always fulfilled in legal clinics of Ukraine.

According to the Association of Legal Clinics of Ukraine (2019), the Congress of Legal Clinics attended the invited speakers representing the legal clinical communities of Great Britain, Germany and Italy and Poland - J. Hall, U. Stege, Ph.F. Czernicki, P. Klimek in October 2019. They emphasized that the future is after legal clinical education. Therefore, the current stage of legal clinics development is characterized not only by the provision of free legal aid to socially vulnerable groups, international cooperation, but also by the deployment of broad activities on legal education and informing the population about changes in current legislation. Also for the modern period the introduction of training courses into the content of higher professional education to study the theoretical and methodological aspects of the legal clinics organization and functioning is inherent (Yelov, 2004).

Legal clinics today can provide effective legal activities, and legal clinical activities are now an integral part of legal education in both Ukraine and Europe. In addition, participation in the legal clinics activities has a significant impact on raising the level of legal awareness and culture of both the students and those who are counseled. Therefore, such a model should lead to the formation of a broad outlook of a lawyer, on the one hand, and should be oriented to a certain level of legal education, and on the other hand, it should include requirements as to the level of knowledge and skills in certain types of legal activities.

Introduction of legal clinical education into the higher legal education system will allow to provide: to students - practical professional activities experience, to consolidate theoretical knowledge obtained during training and during practice; to vulnerable social groups - quality legal assistance, the ability to protect their rights and legitimate interests; to higher education institutions - a base for students to do their educational practice, new forms and methods of practical students training, guarantee of highly qualified specialists graduation; to the state - high level of legal education and legal culture within the state, access to free legal aid of vulnerable social groups.

\section{Conclusions}

We had the opportunity to analyze and reveal the theoretical, methodological and applied principles of legal clinical education and the legal framework for the legal clinics' organization and functioning in Ukraine. on the basis of the achievements of modern domestic and foreign scientists. Legal clinical education provides students' mastering of theoretical aspects through the introduction of the appropriate training course into the curriculum, practical incorporation into the real legal situation through the legal clinics establishing and functioning within the structure of universities.

At present, legal clinics in Ukraine are in the making and are an indicator of the quality legal education provided by higher education institutions. It is crucial to develop and popularize legal clinics among the population, as foreign practice shows that legal clinics benefit all of us: lecturers, students, higher education institutions, and ordinary people who are in need of legal assistance. It can be concluded that, during its existence in Ukraine, legal clinical education has made a huge step forward from the first student-initiated legal clinics to full-fledged entities providing legal assistance to vulnerable groups of the population.

The modern development of legal clinical education in Ukraine requires further improvement, which provides for the legal fixing of a specific type of legal education - legal clinical education; signing and implementing the provisions of the draft Concept of Legal 
Education Development in the aspect of the activities of legal clinics; separation in all institutions of higher education of legal clinics in a separate structural unit with the staff. Thus, the conclusions and results of the article may serve as a basis for new scientific research.

\section{References}

Association of Legal Clinics of Ukraine. (2019). Retrieved from: https://legalclinics.in.ua/pidsumky-zyizdu-konferentsiyi-ayuku-2109/.

Cantatore, F. (2020). Pro bono in law schools: tracking the effect of pro bono service in an Australian University Law Clinic. International Journal of Clinical Legal Education, 27(1), 101-136. DOI: http://dx.doi.org/10.19164/ijcle.v27i1.878.

Draft concept for the development of legal education. (2020). Retrieved from: http://kno.rada.gov.ua/news/main_news/75465.html.

Constitution of Ukraine. (1996). https://zakon.rada.gov.ua/laws/show/254к/96-вp.

Regulation "On the Legal Clinic "Istyna" of the DSUIA". (2017). Dnipro: Publishing House of the DSUIA. Retrieved from: https://dduvs.in.ua/en/.

Dubchak, N.S. (2013). Experience in the organization and functioning of legal clinics in countries of the Anglo-American legal system. Scientific Bulletin of Uzhgorod National University. Law Series, 21/II(1), 36-38.

Figel, Yu.O. (2011). Role of legal clinics in formation of law students' ability to implement law. Lviv: Lviv State University of Internal Affairs.

Halai, A. (2014). Establishing of legal clinical education in Ukraine and some other countries in the world. Scientific Journal of the National Academy of Public Prosecutor of Ukraine, 4, 39-48.

Halai, A. (2009). Ways of introducing a course of legal clinical education into the educational process of higher educational establishments of Ukraine. Law of Ukraine, 1, 16-21.

Halai, A.O. (2005). Pedagogical characteristics of legal clinical education. Bulletin of the Association of Legal Clinics of Ukraine, 2, 2-3.

Khudoykina, T. (2014). A law clinic as an innovative method of teaching law students. Integration of Education, 1, 19-24.

Khudoykina, T.V., Lysenko, V.V. (2017). Development of clinical education as important component of legal education modernization. Integration of Education, 21(1), 124-137. DOI: 10.15507/1991-9468.086.021.201701.

Kuchuk, A.M., Serdiuk, L.M., Zavhorodnia, Y.S. (2019). Modern law education in the context of natural understanding of law. Asia Life Sciences, 21(2), 359-370.

Levitan, K.M., Yuhova, M.A. (2004). Formation of democratic values in law students. Education and Science, 3(27), 61-69.

Lodzhuk, M.T. 2015. Law clinics in Ukraine: education and legal assistance. Odessa: Phoenix.

Meshcheryakov, E.I., Petrushin, A.I. (2013). Training in law clinic and development of communicative competence of law students. Siberian Psychological Journal, 4, 59-64.

Nemytina, M.V. (2004). On methodological approaches in modern clinical legal education. Law and Education, 4, 105-110.

Order of the Ministry of Education and Science of Ukraine No. 592 "On Approval of the Standard Regulation on the Legal Clinic of a Higher Educational Institution of Ukraine". (2006). Retrieved from: http://search.ligazakon.ua/1_doc2.nsf/link1/RE12830.html.

Polyakov, A.O. (2010). Law Clinical Education: historical Experience and the Present Days. Teacher Discours, 8, 185-191.

Register of Legal Clinics of Ukraine. 2019. Retrieved from: https://legalclinics.in.ua/wpcontent/uploads/Reyestr-AYUKU-2019-Forum2019.pdf.

Savelova, Yu.M. (2013). Historical and legal aspect of the emergence and development of legal clinical education. Small and Medium Business (Law, State Economy), 1, 36-42.

Sokolenko, O.L. (2009). Legal clinic in law education activities. Bulletin of the Academy of Customs Service of Ukraine. Series: Law, 1, 40-44. 
Vlasiuk, V. (2018). Why Ukraine Needs Legal Clinics. Retrieved from: https://life.pravda.com.ua/columns/2018/04/12/230236/

Yelov, V.A. (2004). Formation of individual professional skills of a lawyer working with a client in law students. Lutsk: Vezha. 